\title{
Media literacy as a cross-sectoral phenomenon: Media education in Finnish ministerial-level policies
}

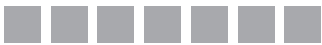

Lauri Palsa

ORCID: 0000-0001-7711-2746

NATIONAL AUDIOVISUAL INSTITUTE, FINLAND

Saara Salomaa

ORCID: 0000-0003-1220-9533

NATIONAL AUDIOVISUAL INSTITUTE, FINLAND

https://doi.org/10.19195/1899-5101.13.2(26).2

\begin{abstract}
In international comparisons, Finland has often appeared as a frontrunner in promoting media literacy, especially from the perspective of national-level policies and structures. In this study, our aim is to broaden knowledge about the meaning of media education in the Finnish ministeriallevel policy framework by examining in which administrative sectors policy documents concerning media education have been published and how the concepts of media education and media literacy have been framed. The results suggest that media education and media literacy are addressed widely across the different administrative sectors in Finland, but mostly by the Ministry of Education and Culture. There is also variance in the ways in which the concepts are presented in the policies. In the article, eight identified frames of media literacy are discussed, including protectionism, cultural participation, future working competences, inclusion, broad media education, democracy, national security, and cosmopolitanism. The article highlights the importance of nuanced understanding of the meanings and limits of media education and research-based policy development.
\end{abstract}

KEYWORDS: media literacy, media education, policy, policy analysis, frame analysis, Finland

\section{INTRODUCTION}

Various forms of media play a significant role in the societies, cultures, and lives of individuals in today's globalized world. Digitalization, new and evolving technologies, innovations, and broadening media landscapes are just a few examples of the trends that educators must consider when determining the knowledge, skills, and abilities that people need not only in today's world, but also in the future. This is especially 
important in media education, which refers to the process of developing learners' media literacy (Buckingham, 2003, 2019). This need is also acknowledged by policymakers (Potter, 2013). For example, in Europe, the importance of promoting media literacy is recognized at the level of international policies. In November 2018, the Council of the European Union adopted the revised Audiovisual Media Services Directive (AVMSD). According to the directive (EU 2018/1808), the member states shall promote and take measures for the development of media literacy skills. However, there is a lack of knowledge on how different countries in Europe approach media literacy and how this is taken into account in national policies (van Audenhove et al., 2018, p. 60).

In international comparisons, Finland has often appeared as a frontrunner in promoting media literacy. This has especially been the case from the perspective of the extent to which media education is taken into account in national-level policies and structures (see, for example, Carlsson, 2018; Celot, 2009; Dunås, 2013; Manninen, 2018). Tomljenović (2018, pp. 6) refers to Finland as "the most successful European country in this particular field", based on, for example, the legislative-level recognition of media education, the broad dissemination of practical media education through several public services, and the well-established culture of cooperation between different media education organizations. Finland also scores highest in the Media Literacy Index (Lessenski, 2019) based on more general societal factors, including trust in society, media freedom, and the level of education. Finland was one of the first countries in the world to include media education in its national core curriculum: mass media education was introduced into basic education curricula in 1972 (Kauppinen, 2010; Kupiainen, 2010; Ruokamo, et al., 2016). The Ministry of Education and Culture has supported the promotion of media literacy actively through resource allocation, information management, and policy development since the early 2000s, and in 2012, a government-level public authority with a legal obligation to promote media education was established.

The importance of a media literacy policy has been argued from many different perspectives, such as the development of societies and ensuring the equality of people and cultures (UNESCO, 2013, pp. 12-13). In 2018, the Council of the European Union issued a revised Recommendation on Key Competences for Lifelong Learning (Council of the European Union, 2018). These include competences that are essential in terms of an individual's self-expression, health, employability, and social inclusion. In this recommendation, media literacy is included in the digital skills module. According to Kupiainen (2010), media literacy has a dual role in many governmental and international policies, combining social and economic perspectives. From the social perspective, media literacy contributes to social growth and competitiveness, while from the economic perspective, media literacy contributes to the competitive and innovative knowledge economy (Kupiainen, 2010, pp. 335336). According to UNESCO (2013), media and information literacy policies support the development of knowledge-driven, democratic, and open societies. Media literacy policies can help to establish equality among people who have and who do 
not have access to information and media, and to freedom of expression. It is also argued that media literacy policies can support the participation of individuals in discussions and creative engagement through sharing stories, thus protecting, for example, cultural diversity and pluralism (UNESCO, 2013, pp. 12-13).

As for the concept of media literacy itself, the development of a media literacy policy is not a clear-cut phenomenon. For example, UNESCO has recognized several different approaches to designing media literacy policy, including a human rights-based approach, an empowerment approach, a knowledge societies-based approach, a cultural and linguistic diversity-based approach, and a gender and development-based approach (UNESCO, 2013, pp. 20-23). From a broad perspective, media education is not limited to certain actors or target groups; it is relevant for organizations and individuals from all sectors of society, including public, private, and the third sector, the civil society. Although activities aimed at children and young adults constitute the most common starting point of media education in educational systems, the development of media literacy for adults is also important (see, for example, Palsa \& Ruokamo, 2015; Potter, 2013; Teurlings, 2010).

The notions of broad scope, diversity, and priority, as related to media literacy policy, create the basis for analysis through the pursuit of a contextual conception of media education. Since media literacy is a topic whose meaning is noted within various international policies, it is important to have a more nuanced understanding how it is addressed in the national settings. Thus, our purpose is to study how media education is understood within the Finnish policy framework. In this article, the policy framework is understood as the combination of the public documents published by ministries responsible for different administrative sectors. The documents are analyzed to understand how the media education and media literacy concepts are framed in Finnish ministerial-level policy documents. The research questions guiding this study are the following:

RQ1: In which administrative sectors is media education addressed within the Finnish ministerial-level policy framework?

RQ2: How is media education framed within the Finnish ministerial-level policy framework?

Media education is part of several international policy initiatives of, for example, the EU and international organizations such as UNESCO (Kotilainen \& Kupiainen, 2014; Kupiainen, 2010; UNESCO, 2013). An examination of national policy frameworks may facilitate the development of a contextual understanding of certain topics and phenomena. Through national analyses, it is possible to scrutinize and evaluate the relationship, between national policies and specific contexts, and international policy developments and trends.

As the importance of media literacy is more and more recognized by various international actors and policymakers, more contextual research is needed on situating media literacy in different policy areas. In addition, as the conceptual diversity 
of media literacy is recognized (see, for example, Palsa \& Ruokamo, 2015; Potter, 2013), conceptions of media literacy in policies cannot be taken for granted (see also Wallis \& Buckingham, 2019). Study of the national policy framework offers an excellent opportunity to understand better from an empirically grounded perspective the role of media education among the different policy areas, along with the different ways the concept has been framed. This can help to situate media education and media literacy within the policy framework, to identify relevant governmental stakeholders, and to understand the multifacetedness of media literacy.

This paper is organized as follows. Firstly, we provide a contextual background of the current knowledge of media education in Finnish policies. Secondly, we present and explain the research questions and describe the design of the study. Thirdly, in the results section, we present our findings regarding the role of media education in the different administrative sectors. In addition, the results gleaned from analyzing the frames of media education in the Finnish policy framework are presented. Finally, in the conclusion, we discuss the results from a more theoretical perspective in relation to the media literacy research discussion. We conclude by discussing the study's limitations and suggesting recommendations for further research.

\section{MEDIA EDUCATION IN FINNISH POLICIES}

Media education's importance in various policy areas is not surprising when considering the evolving meaning of media in society and culture, and in the lives of individuals. Besides education policy, communication, technology, and culture are also examples of policy areas where media literacy is often presented (UNESCO, 2013, p. 20). Within the Finnish policy framework, media education can be understood to have a dual position; that is, media education is specifically addressed within its own national policy, but it is also integrated within a broader collection of nationallevel policies in different sectors. From a contextual perspective, it is important to understand that even though the role of media literacy in the Finnish policy framework is recognized, differences and trends are also identified. For example, according to Ulla Carlsson (2018, p. 174), media education in Finland has been addressed from protectionist and democratic perspectives, but questions related to the labor market and growth politics are more evident. Although the present article particularly focuses on ministerial-level policies, it is important to acknowledge the role of policies produced by other organizations within the governmental institutions. For example, the National Agency for Education is responsible for the development of the curricula that, as normative guidelines for education providers, have a great influence on media education practices in the educational system. In the latest curriculum reform, media literacy - in relation to multiliteracy - became part of the curriculum framework from early childhood education to upper secondary education (Halinen, Harmanen, \& Mattila, 2015; Mertala, 2018). 
Besides the broader Finnish policies that address wider policy areas such as children and youth policies, audiovisual culture, or even government programs, but also include media education and media literacy, specific media literacy policies have been introduced (Dunås, 2013; Jaakkola, 2018). The first ministerial-level guiding policy document regarding media education and literacy was published in 2004 in the form of a Ministry of Education draft for an action program concerning children and media violence. The program included specific actions to develop media education nationally. Three years later, in 2007, the Ministry of Education published a proposal for an action program to develop media skills and knowledge as part of the promotion of a civil and knowledgeable society (Ministry of Education, 2007). Furthermore, in 2011, the Finnish National Board of Education published the action program 'Children and Young People as Media Participants', which focused on media education to support participation. In 2013, the Ministry of Education and Culture published 'Good Media Literacy: National Policy Guidelines, 2013-2016', which provided goals and measures relating to four thematic topics: everyday media education focused on children and adolescents; sustainable structures to help pursue and institute media education; stakeholder profiling and partnerships; and Finland's active role in global efforts. These policy guidelines have been implemented in various ways in the field of Finnish media education. According to Palsa and Salomaa (2016), media education in accordance with the Good Media Literacy policy guidelines has been conducted and developed by placing a particular emphasis on supporting the practices and competences of educators and by promoting networking. The latest national media literacy policy was published in December 2019 by the Ministry of Education and Culture (Ministry of Education and Culture, 2019). The main change from the previous policy document (Ministry of Education and Culture, 2013) is the broadened scope of including media education for adults as well as children and young people.

The diversity and multifaceted aspects of media education are evident both in the variety of different policy areas relevant to the topic, such as library, youth, and cultural policies (Päajärvi \& Palsa, 2015) and in the ways in which the subject positions are constructed in relation to media education in the Finnish policies (Uusitalo, 2015). According to Uusitalo (2015), media literacy policy documents published in the administrative sector of the Ministry of Education and Culture have constructed different subject positions for those taking part in media education. According to Uusitalo's findings, these positions include protected, employable, participating, flexible learner, transnational, and critical positions. These subject positions illustrate the different constructions of subjects that it was hoped media education would produce. According to Uusitalo (2015, p. 13), these subject positions entail "different notions of media literacy and action" and are constructed in relation to different discourses.

In the current study, the policies are examined from a supplementary perspective. Rather than focusing on specific document types, such as central media literacy 
policies, or specific administrative sectors (Kotilainen \& Kupiainen, 2014; Pääjärvi \& Palsa, 2015; Uusitalo, 2015), the work of organizations implementing media literacy policy (Wallis \& Buckingham, 2019), or the relationship between public discussion and policy formulation (Van Audenhove et al., 2018), our aim is to include nationally all ministerial-level policy documents in which media education or media literacy are addressed. This provides a broader approach to understanding the different ways in which media education is framed in the Finnish policy framework. The aim of the study is to understand in which administrative sectors media education has been addressed, and how the topic is framed in the policy documents.

\section{METHODOLOGY}

This study focuses on electronically published ministerial-level policy documents in which media education or media literacy are mentioned. Ministries produce different kinds of documents as part of their governmental practices. The published documents have special significance, since ministries, as part of the central government, take on powerful positions in Finnish society. From this perspective, the documents published by the different ministries form a meaningful and interesting research subject. We define policy documents broadly as all documents published by the different Finnish ministries, and include documents that meet the following inclusion criteria:

- The concepts of media education and/or media literacy are mentioned in the document.

- The document was published by a Finnish government ministry.

- The document was published electronically.

Policy documents were searched in January 2020 using "media education" (in Finnish, mediakasvatus) and "media literacy" (in Finnish, medialukutaito) as search terms; the search focused on the whole text. The documents were identified by searching three separate data sources:

1) The institutional repository Valto (https://julkaisut.valtioneuvosto.fi), which includes the publication series of all Finnish ministries from the beginning of 2016, and some publications that date further back. Valto holds 12,068 documents, of which 347 mention either media education $(\mathrm{N}=211)$ or media literacy $(\mathrm{N}=136)$.

2) The Finnish government database of ministries' publications (https://valtioneuvosto.fi/julkaisut). This database holds 8,120 documents, of which 278 mention either media education $(\mathrm{N}=162)$ or media literacy $(\mathrm{N}=116)$.

3) The websites of individual ministries, ${ }^{1}$ from which were drawn 244 documents that mention either media education $(\mathrm{N}=141)$ or media literacy $(\mathrm{N}=103)$.

In total, 869 policy documents mentioning media education or media literacy were retrieved for further examination. These 869 documents were evaluated based on exclusion criteria. All duplicates and translated versions of the documents were excluded, which left 211 documents in the final set for further data analysis. 
To illustrate the different roles of the analyzed documents, we grouped the data source documents into two categories: 1) informative documents $(\mathrm{N}=137)$, such as various types of report, memoranda, and guide, and 2) guiding documents ( $\mathrm{N}=74)$, such as different kinds of program, strategy, and guidelines.

Since the data search took place in January 2020, the scope was electronically available documents published in 2019 and before by Finnish ministries. According to this dataset, the first Finnish ministerial-level published document mentioning media education and/or media literacy dated from the year 2000. The greatest number of policy documents mentioning media education and/or media literacy was published in 2009 (N=22). From the year 2000 onwards, Finnish ministries published an average of around 11 policy documents mentioning media education/ media literacy annually.

The study aims to focus on how media education is framed in Finnish policy documents; for example, what topics media education is connected to, in which contexts media education is addressed, from which perspectives media education is considered, and for kinds of challenge is media education referred to as a solution. Media literacy is a widely used concept that has been defined in various ways in policy documents. However, the concept is sometimes used without an explicit definition (Palsa \& Ruokamo, 2015; Potter, 2013). Thus, this study not only focuses on the definition of the concept, but also takes a broader contextual approach to understand the meanings assigned to the central concepts of media literacy and media education. Both of these concepts are included in this study based on their close relationship and their interchangeable use, which has been noted by, for example, Martens (2010, p. 2).

Rather than focusing of the definition of media education as such, we decided that it was more beneficial to take into account the wider context of how media education is addressed. For this reason, the data are analyzed using qualitative framing analysis, tracing the contextual uses of the concepts of media education and media literacy, conceptualized as frames. Based on the conceptualization of framing by Entman (1993), our aim is to understand the perspectives from which media education and media literacy are addressed in the Finnish ministerial-level policies. This helps us to evaluate which aspects are made salient and which are omitted. The frame analysis methodology is widely used in various disciplines, including media and political studies (Reese, Gandy, \& Grant, 2003; see also Lepik \& Merimaa's article in this special issue), and one of its strengths is its flexibility. The method can be used to analyze different kinds of media text, in this case policy documents.

In this study, the framing analysis was done by identifying those policy documents addressing media education or media literacy published by the different ministries in Finland, recognizing in what textual contexts the studied concepts are presented and examining the meanings the concepts are given in the analyzed documents. This means that even though frames can define problems, diagnose 
causes, make moral judgments, and suggest remedies (Entman, 1993, p. 52), the main focus in this policy study was to understand to what rationales media education and media literacy were given by the ministries and with what kinds of policy objective the concepts were associated.

A sample for analysis of the qualitative data gathered as described was created by collecting textual excerpts from all policy documents in which the concepts of media education and media literacy were addressed. This was achieved by locating all mentions of the concepts of media education and media literacy in each document and copying all the mentions with their textual contexts (for example, the paragraphs mentioning media literacy and media literacy) into a separate document for analysis.

After the data from the policy documents were isolated, the qualitative data were explored and scrutinized several times to get a general understanding of the material. Data were analyzed using conventional content analysis (Hsieh \& Shannon, 2005). The textual data excerpts were examined in a comparatively manner in relation with each other based on their thematic similarities and differences. Based on this phase, eight categories were identified, illustrating the different ways in which media literacy has been framed in the Finnish policy framework.

\section{RESULTS}

Our first research question inquired into the administrative sectors in which media education was addressed within the Finnish ministerial-level policy framework. Media education was addressed in 211 policy documents covering ten different administrative sectors, as shown in Table 1, illustrating the division of retrieved policy documents between the different ministries. A great majority of the documents - over half of them - were published by the Ministry of Education and Culture (52\%). Otherwise, media education was addressed at a much lower level (around 9\%) in transport and communications, social affairs and health, and in documents from the Prime Minister's office.

Based on the number of documents found and the division between the different administrative sectors, the results suggest that media education and media literacy are concepts used widely in the Finnish ministerial-level policy framework. Even though media education and media literacy are taken into account widely in the different administrative sectors, the topics within the policy framework seem to be mostly related to administrative sectors of education and culture, but also relating to questions of communications, social affairs, and health. It is also notable that despite the cross-sectoral nature of media education, the topic is not addressed in all of the administrative sectors. In this study, no policy documents addressing media education and/or media literacy were found in the administrative sector of either the Ministry of the Environment or the Ministry of Economic Affairs and Employment. 
Table 1. Division of analyzed policy documents by ministry

\begin{tabular}{|l|c|c|}
\hline \multicolumn{1}{|c|}{ Ministry } & N & $\%$ \\
\hline Ministry of Education and Culture & 110 & 52.1 \\
\hline Ministry of Transport and Communications & 20 & 9.5 \\
\hline Ministry of Social Affairs and Health & 19 & 9.0 \\
\hline Prime Minister's Office & 19 & 9.0 \\
\hline Ministry of Justice & 15 & 7.1 \\
\hline Ministry for Foreign Affairs & 12 & 5.7 \\
\hline Ministry of the Interior & 11 & 5.2 \\
\hline Ministry of Finance & 3 & 1.4 \\
\hline Ministry of Defense & 1 & 0.5 \\
\hline Ministry of Agriculture and Forestry & 1 & 0.5 \\
\hline Ministry of the Environment & 0 & 0.0 \\
\hline Ministry of Economic Affairs and Employment & 0 & 0.0 \\
\hline Total & 211 & 100.0 \\
\hline
\end{tabular}

Source: Authors.

Our second research question deals with the frames, asking how media education is framed within the Finnish ministerial-level policy framework. The second outcome of this study reveals the qualitative nature of media education in the Finnish policy framework. Based on qualitative frame analysis, eight frames of media education were found within the analyzed policy documents. Table 2 presents the different frames and their division. The total number of cases in the frame analysis presented in Table $2(\mathrm{~N}=233)$ is larger than the total number of analyzed policy documents $(\mathrm{N}=211)$, because in 18 of the analyzed documents, media literacy and/ or media education were framed from two or more perspectives. This table shows the quantitative division between the different frames.

According to the analysis, media education in the Finnish ministerial-level policies is framed from various different perspectives, illustrating the multifaceted and diverse nature of the topic. Media education is most commonly framed from the perspectives of protectionism, cultural participation, future working competences, and inclusion. The broad scope of media education is also explicitly highlighted in many of the policy documents. Based on the analysis, media education is commonly framed from a democratic perspective. Other frames identified in this study address media education from the perspectives of national security, cosmopolitanism, and wellbeing. Even though the identified frames have distinct features, the 
perspectives are not mutually exclusive, but rather interconnected and complementary. The main differences are related to the presented aim of media literacy and the rationale explained. The variety of the frames illustrates how the same concepts can be understood from different perspectives and utilized for different purposes.

Table 2. Frames of media education

\begin{tabular}{|c|c|c|c|}
\hline Frame & Frame description & $\mathrm{N}$ & $\%$ \\
\hline Protectionism & $\begin{array}{l}\text { Media education framed as a way to } \\
\text { develop individuals' media literacy to } \\
\text { protect them from risks. }\end{array}$ & 55 & 23.6 \\
\hline Cultural participation & $\begin{array}{l}\text { Media education framed as a way to } \\
\text { support people's participation in culture. }\end{array}$ & 36 & 15.5 \\
\hline Future working competences & $\begin{array}{l}\text { Media literacy framed as a competence } \\
\text { needed in future working life. }\end{array}$ & 31 & 13.3 \\
\hline Inclusion & $\begin{array}{l}\text { Media education framed as a way to } \\
\text { develop inclusivity in the mediated } \\
\text { world (i.e., overcoming the digital } \\
\text { divide). People's equal right to media } \\
\text { literacy is highlighted. }\end{array}$ & 29 & 12.4 \\
\hline Broad media education & $\begin{array}{l}\text { Media education explicitly framed } \\
\text { through its broad scope and diversity- } \\
\text { for example, concerning the topics and } \\
\text { perspectives involved. }\end{array}$ & 24 & 10.3 \\
\hline Democracy & $\begin{array}{l}\text { Media education framed as a way to } \\
\text { promote media literacy, which is a } \\
\text { central competence for participating in } \\
\text { society in the mediated world. }\end{array}$ & 21 & 9 \\
\hline National security & $\begin{array}{l}\text { Media education framed as a way to } \\
\text { promote media literacy to counter } \\
\text { national security risks (i.e., radicaliza- } \\
\text { tion, violence). }\end{array}$ & 17 & 7.3 \\
\hline Cosmopolitanism & $\begin{array}{l}\text { Media education framed as a way to } \\
\text { promote intercultural understanding } \\
\text { and global joint responsibility. }\end{array}$ & 13 & 5.6 \\
\hline Wellbeing & $\begin{array}{l}\text { Media education framed as a way to } \\
\text { support individuals' wellbeing in the } \\
\text { mediated world. }\end{array}$ & 7 & 3.0 \\
\hline
\end{tabular}

Source: Authors.

The frames are further explained and discussed in the subsequent sections of this chapter. In addition, data extracts (translated from Finnish by the authors) are 
presented to help understand the different frames. In the frame -specific sections, the commonness of the frames among the different administrative sectors is also described.

\section{Protectionism}

Media education was most commonly framed as a form of protection from different risks (24\%). In this sense, media education develops media literacy to protect individuals from different media-related risks. Based on the data analyzed in this study, such risks can be, for example, media violence, bullying, crimes, hate speech, pornographic content, and economic risks. The following data extraction illustrates one example of media education designed to protect children from a media-related risk.

The first and foremost goal is to decrease the media violence targeted at children. Media education is one of the most important ways to accomplish this (Document 50).

In the following excerpt from the data, media education is intended to help develop a safe media environment as part of the information society, with children and young people as the central focus point.

Children and young people are in the front row of implementing the new technology. However, the ability to use technology alone is not enough to guarantee successful growth in the constantly changing environment of the information society. For that, they need media education to provide guidance to understand the information society and to deal with an endless stream of information, the means to protect themselves from the harmful, illegal, and unwanted content, the readiness to report startling or scary content and activities, and the readiness to utilize the influencing and communication possibilities offered by the technology (Document 110).

A protectionist perspective on media education is common among different administrative sectors. However, most of the documents in which media education is framed from a protectionist perspective are published by the administrative sectors of the Ministry of Education and Culture $(\mathrm{N}=24)$ and Ministry of Transport and Communication $(\mathrm{N}=12)$. The prevalence of the protectionist perspective on media education in the ministerial-level policy framework is understandable, since the protectionist tradition in media education has been well recognized and discussed in the academic literature, but it has also been debated (see, for example, Hobbs, 2011; Potter, 2010). A protectionist perspective is also acknowledged within the media literacy policy in the UK (Wallis \& Buckingham, 2019). Public discussion concerning the negative features of media does not inevitably result in similar policy development. For example, in Flanders, Belgium, the media have been discussed from a protectionist perspective, but the policies formulated are based more on a philosophy of empowerment (Van Audenhove et al., 2018, pp. 76-77).

\section{Cultural participation}

The next most common means of framing media education was to construct it as promoting cultural participation (16\%). Through this frame, media education was 
described as a tool for marketing cultural participation possibilities by developing media literacy. The frame of cultural participation connected media education to art education, cultural heritage education, and cultural education. In the following data extract, media education can be understood as supporting the consumption of certain types of media.

From the point of view of consumption, a media-literate person can appreciate and choose diverse and responsibly produced contents (Document 44 ).

In the analyzed policy documents, media education was also referenced as a means for people to access and to participate in culture and cultural discussions. The following data extract illustrates the meaning of media literacy for cultural participation.

Cultural discussion is transferred increasingly to social media, whereupon professionally produced content (cultural journalism, professional critique) is threatened by commercial pressures. As the audio-visual culture is emphasized in media literacy, the skills required to use media are more needed in all age groups (Document 152).

Among the administrative sectors, media education is considered mostly from the cultural participation perspective in documents published primarily by the Ministry of Education and Culture (N=29). Since media in its different forms plays a significant role in today's cultures, media literacy can open up opportunities for people to get involved and to participate in culture in different ways. For example, Burgess (2007) has analyzed the role of media literacy for cultural participation in photography-related digital networks.

\section{Future working competencies}

One of the frames of media education analyzed in this study considers technological development and its influence on the skills, abilities, and competencies needed by citizens (13.3\%). The frame of future working competencies illustrates the ways in which media education is seen to promote the different competencies required in the future. These new competencies include, for example, media literacy, as the next data extract illustrates.

It is evident that we need a new way of dealing with information, both receiving and producing. We need to be better able to select information, to filter the relevant messages quickly, and to edit them into knowledge meaningful for us; we need critical media literacy (Document 55).

Media education is understood as a way to develop the competencies needed in the future by both children and adults. The next data extract illustrates the kind of media literacy it is thought adults will need in the future.

In this new environment, adults also need a new kind of media literacy. Skills are needed to understand the functioning of digitalized devices and their use of digital services. Requirements for media literacy are not bounded only by technical skills. This means the ability of adults to create a meaningful relationship with the different forms of electronic media and the new contents that they offer, which grows quickly in significance with the spread of all kinds of information (Document 198). 
Based on the analysis, media education is mostly framed from the perspective of future working competencies in the administrative sector of the Ministry of Education and Culture $(\mathrm{N}=22)$. This is understandable, since the ministry is responsible for education, and thus future working competencies are relevant. However, it is noted that in this study no media education documents were found in the administrative sector of the Ministry of Economic Affairs and Employment, which is responsible for issues related to working life. Taking into account the role of digitalization and evolving technology, media literacy has been seen as one of the central skills in future working life (see, for example, Weng, 2015).

\section{Inclusion}

Based on the content in many policy documents, media education also supports inclusion in society (12\%). These documents highlight the opportunities for different kinds of participation presented by media in their different forms. For example, it is recognized that people have different opportunities to use media in participatory way, which adds to the so-called 'digital divide' between people. The relationship between the concepts of media literacy and the digital divide is clear in the following data excerpt.

The depth of the digital divide can be evaluated based on mastering abilities to use the devices needed in the information society and media literacy (Document 62).

Media education is also presented as an avenue for social participation. From this perspective, it is framed in the data as a support for citizens' social and societal inclusion. The next data extract illustrates how media education is framed as a way to support the participation of a specific population segment, immigrants in this case.

Media education is an important part of social integration: in addition to ICT skills, the production and critique of media content should also be taught. The aim is to increase the participation of immigrants in the media culture, to support active citizenship, and to increase the feeling of involvement (Document 42).

Media education was mainly framed as a way to promote inclusion in the documents published by the Ministry of Education and Culture $(\mathrm{N}=12)$ and the Ministry of Social Affairs and Health (N=7). Müller, Sancho, and Hernández (2009) have scrutinized the relationship between media literacy and inclusion in the mediated society: according to them, evolving digitalization is connected to broader social concerns such as disadvantaged minorities, long-term poverty, access to resources, or equal opportunities for all citizens.

\section{Broad media education}

In 24 analyzed documents (10\%), broad scope and versatility were explicitly highlighted as defining features of media education. These are referred to as the framework for the broad media education. An illustrative feature of this frame is explicitly 
recognizing the broader scope of the topic rather than focusing only on certain aspects of media education or media literacy. In the following data extract, awareness of versatile media literacy is highlighted.

Media literacy should be seen as comprehensive capabilities related to children's and adolescents' life management and education. Media literacy is not only about information, skills, competence, and mastering the use of media; it is a way of existing and living in a relationship with media. Awareness and understanding of versatile media literacy should continue to be strengthened (Document 30).

The broad scope of media education was also encompassed in efforts to understand different media educational activities referenced in the policy documents. The following data extract illustrates how the broad scope of media education is explained when reporting the aims of a project.

In the project 'The development needs of media education', the central activities of the field of Finnish media education were mapped during the spring of 2005. The aim was to understand the diverse field of media education, beginning with the possibilities and development needs related to activities (Document 78).

The frame of broad media education was most prevalent in the documents published by the Ministry of Education and Culture $(\mathrm{N}=14)$. The broad scope and versatility of media education is acknowledged by various authors (see, for example, Martens, 2010; Palsa \& Ruokamo, 2015; Potter, 2013) who have highlighted the diverse nature of media literacy in academic discussions. Since media literacy can be understood in a variety of ways, Palsa and Ruokamo (2015) have discussed the importance of contextual definitions and conceptual clarity.

\section{Democracy}

In 21 of the analyzed policy documents (9\%), media education was framed as a way to promote the use of media for democratic participation. In the democratic frame, media education was connected to education about democracy. In the following data extract, media literacy is defined as a precondition for the democratic development of society. According to the analyzed documents, media literacy can be promoted through media education provided in various areas of society. Related to this, the following data extract also illustrates the variety of media education actors.

Media competence and media literacy are preconditions for the democratic development of the modern information society, enabling the participation of citizens in societal discussions and decision-making. This can be achieved by strengthening media education in schools, youth work, libraries, and non-formal adult education, and as part of the work of non-governmental organizations (Document 4).

In the following data extract, media literacy is related to possibilities of participating in societal public discussions and countering disinformation.

Thirdly, the precondition of an open, democratic society is the ability to have broad societal public discussions. This requires the development of citizens' media literacy and communication, and 
other actions by officials that strengthen the spreading of timely information and reduce the influence of fake news both in normal conditions and during a crisis (Document 118).

Based on the data, the democracy frame of media education was most prevalent in the administrative sector of the Ministry of Justice $(\mathrm{N}=9)$. This is understandable, since the ministry oversees the structure of democracy and the fundamental rights of citizens. Mihailidis and Thevenin (2013) have studied the possibilities for democracy in the current ubiquitous media landscape, arguing that media literacy is one of the central competences for engaged citizenship in a participatory democracy.

\section{National security}

In 17 analyzed policy documents (7\%), media education was framed as a way to strengthen national safety through the promotion of media literacy. Risks relating to national security were threats to national resilience, information warfare, and the spreading of disinformation, radicalization, violence, and extremism. The next data extract refers to media literacy as a way to support the national "durability of strike (iskunkestävyys)". Durability of strike is a figure of speech in the Finnish language describing preparedness and the potential ability to act and to cope in the moment of some (in this case undefined) crisis. In this case the resilience refers to the society.

Media literacy strengthens the resilience of a society. Resilience is endurance during a national crisis. Resilience is the durability of strike that actualizes in the moment of crisis (Document 1).

In the following data extract, media literacy is connected to strengthening the participation of young people and countering propaganda that encourages violence. Youth work in particular is identified as a responsible actor in supporting media literacy for young people. However, the media educational actions that should be implemented in the youth work are not specified.

Youth work can involve carrying out actions that strengthen the participation of young people, media literacy, and their own ability to counter propaganda that encourages violence (Document 31).

Media education was mostly framed from a national security perspective in the documents published by the administrative sector of the Prime Minister's Office $(\mathrm{N}=8)$ and the Ministry of the Interior $(\mathrm{N}=5)$. National security can be addressed from different perspectives. As the first data extract illustrates, media literacy is represented as a way to support the general resilience of a society. This view is shared with the Media Literacy Index, which assesses the resilience of European countries. In the report (Lessenski, 2019, p. 3), media literacy is used to gauge the potential for resilience to various negative effects, such as diminishing public trust, polarized politics, and fragmented media. In the second data extract, media literacy is connected to the prevention of violent radicalization and extremism. With regard to themes used to promote national security through media education, there is much academic interest, for example in relation to countering radicalization (Melki, 2017) and disinformation (Bulger \& Davison, 2018) from the point of view of media literacy. 


\section{Cosmopolitanism}

In 13 analyzed policy documents (5.6\%), media education was framed from a global and international perspective. This frame is referred to as the frame of cosmopolitanism. In the following data extract, media education is connected to the framework of global education, and the aim is to promote global responsibility.

Media education is an important factor in the global education that guides us toward global joint responsibility (Document 9).

According to the analysis, the global perspective on media education can be referenced using multiple terms. In the following data extract, the term 'transnational media literacy' is used to specify a certain global perspective on media education.

The transnational media literacy and its development that covers the whole population requires from the media organizations intercultural understanding, and especially the consideration of different cultural perspectives (Document 42).

According to the data extract above the mentioned transnational media literacy is not designed only for certain groups, but rather relates to efforts supporting media literacy that should encompass all people. It is also notable that media organizations are defined as the central actors promoting media literacy. Even though media-related topics might be most relevant for the Ministry of Transport and Communication, almost all of the policy documents framing media literacy or media education from a global perspective are published in the administrative sector of the Ministry of Education and Culture $(\mathrm{N}=11)$. This might open up possibilities for cooperation between the different administrative sectors to promote non-formal media education conducted by media organizations. In relation to the common themes in the frame of cosmopolitanism, Mills and Green (2013) have discussed the potential of communication media for global citizenship.

\section{Wellbeing}

Media education was seen in seven analyzed policy documents (3\%) as a way explicitly to support the wellbeing of individuals. In the analyzed policies, the relationship between media education and the promotion of wellbeing was explained clearly. The following data extract illustrates how media education is connected to ensuring a safe media environment, and the purpose of both is the promotion of wellbeing, especially among children.

Media education and a safe media environment for children promote the wellbeing of children (Document 51).

In the following data extract, media education is assimilated with film education, and both are connected to media literacy. It is also notable that media education is seen as a way to promote the wellbeing of people in general, rather than focusing on certain groups. 
Media literacy is a central part of media and film education that has the influence to increase the wellbeing of people in the digital era (Document 32).

Most of the policy documents framing media literacy from a wellbeing perspective are published in the administrative sector of the Ministry of Education and Culture $(\mathrm{N}=6)$. Through this frame, there could be new opportunities for other administrative sectors for example for the Ministry of Social Affairs and Health. Wellbeing in the mediated and digitalized world has raised interest in academic discussions as well; for example, Pienimäki (2019) has analyzed the possibility of media education promoting the wellbeing of vulnerable groups.

When analyzing the division of the use of different frames among different administrative sectors, it is noted that ministries have different ways of understanding media literacy and media education in their published policy documents. Thus, the role and meaning of media education and media literacy in the policy areas should not be taken for granted. The role of media education also differs within the specific administrative sectors. In some administrative sectors, such as the Ministry of Education and Culture, media education is framed from many different perspectives - more specifically, documents are published in the administrative frame of media education from the perspectives of cultural participation, protectionism, and future working competences. National security is the only perspective that was not used to frame media education in the administrative sector of the Ministry of Education and Culture, in contrast to the administrative sectors of the Prime Minister's Office, the Ministry of Interior, and the Ministry of Defense.

According to the data analyzed in this study, the first policy document addressing media education in Finland was published in the year 2000. When taking into account the annual division of the policy documents and the identified frames, it is possible to gain a more accurate view of the possible thematic media educational trends. Even though media education is framed most commonly from a protectionist perspective, this perspective was most evident between 2005 and 2010. After that, media education is more commonly framed, for example, from democratic and inclusion perspectives. The latest notable trend is related to the frame of national security, most evident from 2016 onward.

\section{CONCLUSION AND DISCUSSION}

The specific purpose of this study is to supplement the existing understanding of the role of media education in the Finnish ministerial-level policy framework (Kotilainen \& Kupiainen, 2014; Kupiainen, 2010; Uusitalo, 2015). This study supports the notion that media education is not tied to a single administrative sector, but is instead a topic addressed to a certain extent in almost all administrative sectors. In the Finnish policy framework, media education is considered broadly and has a relatively established position within policymaking bodies. However, it is important 
to note that the scope of media education as part of different ministries' publications varies. The data show that over half of the policy documents are published by the Ministry of Education and Culture, whereas policy documents concerning media education were not published by the Ministry of the Environment or the Ministry of Economic Affairs and Employment.

Given that media education is framed as a way to promote the competences needed in the future - as indicated in the frame of future working competences - the lack of a media educational perspective in the policies published by the Ministry of Economic Affairs and Employment draws attention when interpreting the results. It can be argued that this lack is evidence that the responsibility to promote these competences lies with other administrative sectors, such as education. As Uusitalo (2015) found, employability was one of the subject positions constructed in the media education policies of the Ministry of Education and Culture. Another important notion related to the lack of a media educational perspective in the policy framework relates to the Ministry of the Environment. This is notable, since the relationship between media and the environment concerning climate change, for example, is much discussed, and the environmental perspective of media literacy and media education is also highlighted in academic discussions (Cooper, 2011; Lopez, 2013).

One of the main results of the analysis in this study concerns the versatile nature and role of media education in the Finnish policy framework. This highlights the importance of recognizing the different meanings the concept may have, but it also opens up possibilities to find connections with other educational traditions. The different frames of media education identified in this study encourage strengthening the media literacy approach in, for example, democracy education (Kotilainen \& Kupiainen, 2014), art education (Chung \& Kirby, 2009), and global education (Harshman, 2017). This perspective highlights the importance of understanding the contextuality of the educational concepts in use.

From the perspective of policy development, the variance in media education approaches can raise questions. Firstly, it is important to consider that media education can have many different, even opposing, rationales and purposes. For example, media education was mainly framed from a protectionist perspective, rather than from the perspective of wellbeing. This means that even though the concepts can be shared between the administrative sectors, the different sectors may assign different meanings to the terms. Not all media education is in line with all purposes presented in the policy documents. Recognizing the different ways media education is understood and can be framed can help in evaluating the possibilities more realistically. Clear explanations of the purposes of media education and conceptual awareness can help to avoid misunderstandings. In addition, if media education is only addressed from a certain perspective without connecting it to other ways of understanding the concept, the effectiveness of the planned actions can be limited. If media education or media literacy 
is seen as a way to achieve various different goals, the ways in which it is planned to achieve these goals should be explained. Media literacy should not be seen as a silver bullet for various problems without a clear explanation of how to use it.

The diversity of media education that appears through the different frames highlights the importance of deep educational reflection and discussion. Since media education can be understood from different perspectives, the question should not be whether media education is important or not, but rather what kind of media education is important and why. This can open up opportunities for philosophical discussions concerning the aims of education in general and the values that are involved. One way to stimulate discussion is to promote research-based policy development and to connect the findings and presented frames to theoretical academic discussions. This is possible since there is academic interest connected to every frame found in this study.

Although this study takes a relatively broad perspective to its focus on media education in the Finnish policy framework in terms of the administrative sectors and document types included in the analysis, one of its central limitations concerns the scope of the data. In the field of media education, other public agencies and organizations that hierarchically lie under the ministries, such as the National Agency for Education (responsible for curricula development) or the National Audiovisual Institute (the media education authority), are active players in Finland. It is left for future studies to show how media education is framed in the documents published by other actors.

In this study, the specific focus is on the concepts of media education and media literacy. It is important to note that academic literature and policies recognize a variety of other literacies (see, for example, Stordy, 2015) that are relevant to discussions on media education, such as multiliteracy (Palsa \& Ruokamo, 2015), and that could open up new policy research opportunities.

\section{REFERENCES}

Buckingham, D. (2003). Media education: Literacy, learning, and contemporary culture. Polity Press.

Buckingham, D. (2019). The media education manifesto. The Polity Press.

Bulger, M., \& Davison, P. (2018). The promises, challenges, and futures of media literacy. Journal of Media Literacy Education, 10(1), 1-21. https://doi.org/10.23860/JMLE-2018-10-1-1.

Burgess, J. (2007). Vernacular creativity and new media. Queensland University of Technology.

Carlsson, U. (2018). En inledande kommentar. In U. Carlsson (Ed.), Medie- och informationskunnighet $(M I K) i$ den digitala tidsåldern - en demokratifråga. Kartläggning, analys, reflektioner (pp. 173-174). Nordicom.

Celot, P. (2009). Study on assessment criteria for media literacy levels. EAVI.

Chung, S. K., \& Kirby, M. S. (2009). Media literacy art education: Logos, culture jamming, and activism. Art Education, 62(1), 34-39. https://doi.org/10.2307/27696317.

Cooper, C. B. (2011). Media literacy as a key strategy toward improving public acceptance of climate change science. BioScience, 61(3), 231-237. https://doi.org/10.1525/bio.2011.61.3.8.

Council of the European Union. (2018). Council recommendation on key competences for lifelong learning. Council of the European Union. 
Dunås, J. (2013). Media and information literacy in the Nordic countries. In U. Carlsson (Ed.), Medieoch informationskunnighet i Norden: En nyckel till demokrati och yttrandefrihet (pp. 171-214). Nordicom.

Entman, R. M. (1993). Framing: Toward clarification of a fractured paradigm. Journal of Communication, 43(4), 51-58. https://doi.org/10.1111/j.1460-2466.1993.tb01304.x.

Halinen, I., Harmanen, M., \& Mattila, P. (2015). Making sense of complexity of the world today: Why Finland is introducing multiliteracy in teaching and learning 2015. In V. Bozsik (Ed.), Improving literacy skills across learning. CIDREE yearbook 2015 (pp. 136-153). HIERD.

Harshman, J. (2017). Developing a globally minded, critical media literacy. Journal of Social Studies Education Research, 8(1), 69-92.

Hobbs, R. (2011). The state of media literacy: A response to Potter. Journal of Broadcasting \& Electronic Media, 55(3), 419-430. https://doi.org/10.1080/08838151.2011.597594.

Hsieh, H.-F., \& Shannon, S. (2005). Three approaches to qualitative content analysis. Qualitative Health Research, 15(9), 1277-1288. https://doi.org/10.1177/1049732305276687.

Jaakkola, M. (2018). Finland: En lång tradition av mediefostran. In U. Carlsson (Ed.), Medie- och informationskunnighet (MIK) $i$ den digitala tidsåldern En demokratifråga. Kartläggning, analys, reflektioner (pp. 187-197). Nordicom.

Kauppinen, M. (2010). Lukemisen linjaukset: Lukutaito ja sen opetus perusopetuksen äidinkielen ja kirjallisuuden opetussuunnitelmissa [Literacy guidelines: Reading literacy and its instruction in the curricula for the mother tongue in basic education]. University of Jyväskylä.

Kotilainen, S., \& Kupiainen, R. (2014). Media and information literacy policies in Finland. University of Tampere.

Kupiainen, R. (2010). Finnish media literacy policies and research tendencies within a European Union context. International Journal of Media and Cultural Politics, 6(3), 335-341. https://doi. org/10.1386/mcp.6.3.335_3.

Lessenski, M. (2019). Just think about it: Findings of the Media Literacy Index 2019. Open Society Institute.

Lopez, A. R. (2013). Greening the media literacy ecosystem: Situating media literacy for green cultural citizenship. Prescott College.

Manninen, V. (2018). Monitoring media pluralism in Europe: Application of the Media Pluralism Monitor 2017 in the European Union, FYROM, Serbia \& Turkey. Country Report: Finland. Centre for Media Pluralism and Media Freedom.

Martens, H. (2010). Evaluating media literacy education: Concepts, theories and future directions. Journal of Media Literacy Education, 2(1), 1-22.

Melki, J. (2017). Extremism and media uses in Lebanese schools: Digital and media literacy to counter youth radicalization. The role of media and digital literacy in countering violent extremism. Institute of Media Research and Training.

Mertala, P. (2018). Lost in translation? Huomioita suomalaisten opetussuunnitelmien monilukutaitokäsitteen tutkimuksellisista ja pedagogisista haasteista [Lost in translation? Observations about the academic and pedagogical challenges of the concept of multiliteracy in the Finnish core curricula]. Media \& Viestintä, 41(1), 107-116.

Mihailidis, P., \& Thevenin, B. (2013). Media literacy as a core competency for engaged citizenship in participatory democracy. American Behavioral Scientist, 57(11), 1611-1622. https://doi.org/ $10.1177 / 0002764213489015$.

Mills, J., \& Green, B. (2013). Popular screen culture and digital communication technology in literacy learning: Toward a new pedagogy of cosmopolitanism. Journal of Popular Film and Television, 41(2), 109-116. https://doi.org/10.1080/01956051.2013.787355.

Ministry of Education. (2007). Proposal for an action programme for developing media skills and knowledge as part of the promotion of civil and knowledge society. Ministry of Education. 
Ministry of Education and Culture. (2013). Good media literacy: National policy guidelines 2013-2016. Ministry of Education and Culture.

Ministry of Education and Culture. (2019). Media literacy in Finland. National Media Education Policy. Ministry of Education and Culture.

Müller, J., Sancho, J. M., \& Hernández, F. (2009). New media literacy and the digital divide. In L. T. Wee Hin \& R. Subramaniam (Eds.), Handbook of research on new media literacy at the K-12 Level: Issues and challenges (pp. 72-88). IGI Global.

Palsa, L., \& Ruokamo, H. (2015). Behind the concepts of multiliteracies and media literacy in the renewed Finnish core curriculum: A systematic literature review of peer-reviewed research. Seminar.net: International Journal of Media, Technology and Lifelong Learning, 11(2), 101-119.

Palsa, L., \& Salomaa, S. (2016). Kohti parempaa medialukutaitoa: selvitys kulttuuripoliittisten Hyvä medialukutaito 2013-2016 suuntaviivojen mukaisesta mediakasvatustyöstä [Towards better media literacy: Study of the media education work in accordance with the good media literacy 20132016 guidelines]. National Audiovisual Institute.

Pienimäki, M. (2019). Improving the wellbeing of at-risk youth through media participation. Media Practice and Education, 20(4), 364-377. https://doi.org/10.1080/25741136.2018.1541371.

Potter, J. (2010). The state of media literacy. Journal of Broadcasting \& Electronic Media, 54(4), 675696. https://doi.org/10.1080/08838151.2011.521462.

Potter, J. (2013). Review of literature on media literacy. Sociology Compass, 7(6), 417-435. https://doi. org/10.1111/soc4.12041.

Pääjärvi, S., \& Palsa, L. (2015). Entäs aikuiset? Katsaus medialukutaidon edistämiseen digitalisoituvassa Suomessa [What about the adults? Review of the promotion of media literacy in the digitalizing Finland]. Aikuiskasvatus, 35(3), 199-207.

Reese, S. D., Gandy, O. H., \& Grant, A. E. (2003). Framing public life. Perspectives on media and our understanding of the social world. Routledge.

Ruokamo, H., Kotilainen, S., Kupiainen, R., \& Maasilta, M. (2016). Media education today and tomorrow. National Audiovisual Institute.

Stordy, P. (2015). Taxonomy of literacies. Journal of Documentation, 71(3), 456-476. https://doi. org/10.1108/JD-10-2013-0128.

Teurlings, J. (2010). Media literacy and the challenges of contemporary media culture: On savvy viewers and critical apathy. European Journal of Cultural Studies, 13(3), 359-373. https://doi. org/10.1177/1367549410363202.

Tomljenović, R. (2018). Regulatory authorities for electronic media and media literacy: Comparative analysis of the best European practices. Council of Europe.

UNESCO. (2013). Media and information literacy: Policy and strategy guidelines. Paris, France: United Nations Educational, Scientific and Cultural Organization.

Uusitalo, N. (2015). Hallinnan tekemiset: Mediakasvatuspolitiikan diskursiivinen tuottaminen [Doings of governance: The discursive construction of media education policy]. University of Tampere.

van Audenhove, L., Vanwynsberghe, H., \& Mariën, I. (2018). Media literacy policy in Flanders, Belgium: From parliamentary discussions to public policy. Journal of Media Literacy Education, 10(1), 59-81.

Wallis, R., \& Buckingham, D. (2019). Media literacy: The UK's undead cultural policy. International Journal of Cultural Policy, 25(2), 188-203. https://doi.org/10.1080/10286632.2016.1229314.

Weng, W. (2015). Eight skills in future work. Education, 135(4), 419-422. 